\title{
Increasing FX Exposures Unnerved Vietnam Banking Authorities
}

\author{
Quan-Hoang Vuong
}

August 8, 2011

Stratfor Global Intelligence
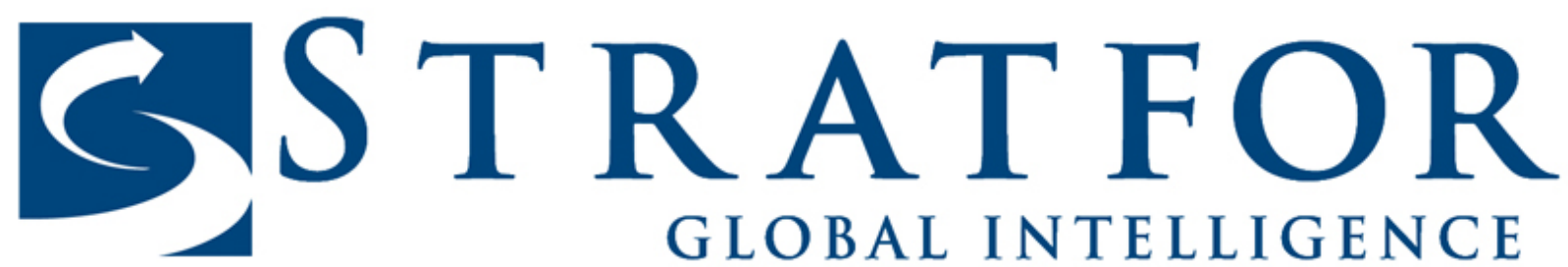

GLOBAL INTELLIGENCE 


\section{Increasing FX Exposures Unnerved Vietnam Banking Authorities}

Partner Perspectives

3 MINS READAug 8, 2011| 05:00 GMT

\section{WWW.VIE- \\ a Quality Insights on ! \\ a Financially and Time-Saving Ts}

Vietnam's money and capital markets continue to see dramatic stages in remaining months of 2011 due to high bank rates and also increasing foreignexchange exposure faced by domestic enterprises.

Le Xuan Nghia of the National Financial Supervisory Committee (NFSC) confirmed that over the first 7 months of 2011, growth rate of foreign exchange borrowing surged by 25.7 percent from the total credit volume extended in forex at the end of 2010. Meanwhile, local currency borrowings expanded by a mere 3.7 pct from 2010 year end.

Nguyen Van Giau - formerly the central bank's Governor - who just took over the post of Chairman of the National Assembly's Economic Committee also said the weak inflow of forex into the economy looked worrisome. Overseas remittance dropped from $\$ 2.4$ billion in Q1-2011 to $\$ 1.9$ billion in Q2. Money from FPI flow dropped significantly to $\$ 0.66$ billion in H1.2011 from $\$ 1.79$ billion in H1.2010. The fact that the central bank has bought an addition of $\$ 4.8$ billion for national reserve would not change the situation much. 
Vu Viet Ngoan - new chief of NFSC - also expressed his concern about a tendency of rising US\$ price in domestic markets towards end of 2011, a situation to him banks would have to struggle to cope with.

This problem, to us - DHVP Research, is man-made. The central bank in order to curb the so-called dollarization has imposed rules on interest rate caps on foreign currency deposits, mostly US dollar. Low deposit rates on US dollar have led to lower cost of lending - most in the range of 7-8 pct p.a. offered by commercial banks, while domestic borrowers have had a choice to stay away from Vietnamese Dong loans - which have been so far prohibitively expensive, usually 19-22 pct p.a.

About $\$ 28$ billion in US Dollar loans has been loaned out to the corporate sector, mostly short-term funding, only appropriate for working capital finance or trade finance. But much of this is believed to go on to fund longerterm fixed assets, leaving the question of maturity mismatch and forex risk exposures a real uncertainty.

Bankers will certainly face tough times ahead. Rate of financial frauds has been on the rise with many bankers and corporate executives being arrested on charges of collusion and cheating for obtaining funds illegitimately. This forex exposure adds another real conundrum to the list of acute problems that banks would need to adequately address in the coming months.

Subscribe to Intelligence Over News

Independent Strategic Analysis | Objective Geopolitical Insights

Copyright @ Stratfor Enterprises, LLC. All rights reserved. 


\section{GST R ATFOR}

Stratfor Global Intelligence

\section{Partner Perspectives}

Published on August 8, 2011

URL: https://worldview.stratfor.com/article/increasing-fx-exposures-unnervedvietnam-banking-authorities 